\title{
SEXUAL PROMISCUITY AMONG FEMALE UNDERGRADUATES IN TERTIARY INSTITUTIONS IN IMO STATE: AN ISSUE FOR HEALTHY LIVING
}

\author{
OKAFOR, H. C. PhD \\ Department of Educational Psychology/Guidance and Counselling, \\ Alvan Ikoku Federal College of Education \\ Owerri \\ email: lettagozie@yahoo.com
}

and

DURU, N. E. MRS

Comprehensive Secondary School,

Amakohia-Uratta

Owerri

email: ngozievangelina@yahoo.com

\begin{abstract}
The study focused on sexual promiscuity among female undergraduates and the attendant health implications. It was carried out in the tertiary institutions in Imo State using 415 final year degree students drawn from four institutions in the State. Three research questions were formulated to guide the study. The design was a descriptive survey. A 12 item questionnaire was structured and validated for the study. Simple percentages were used to answer the research questions. The results indicated the prevalence of sexual promiscuity among female undergraduates, the causes and effects of such unhealthy behaviour on healthy living. Hence, the call for instructional and moral counselling in institutions of higher learning. Recommendations were made based on the findings which, among others was that the counselling Departments in the Universities should organise HIV/AIDS orientation guidance services for greater awareness of the effects of promiscuity. In conclusion, the prevalence and sophistication of sexual promiscuity in the tertiary institutions call for reflections. It is an evil wind that blows no good and should be discouraged in order to maintain healthy female products for productive healthy family living.
\end{abstract}

Key Words: Sexual Promiscuity, healthy living, tertiary institutions. 


\section{Introduction}

Sexual promiscuity is the act of indulging or having sexual intercourse with several causal acquaintances. According to Wehmeier (2000) sexual promiscuity means having many sexual partners. Misi (2008) opines that sexual promiscuity is the use of ones body for the purpose of remuneration or consideration of any form. It could also be addressed as prostitution. This is the type of service given by ladies who want money or who are desperate to attain some certain levels of prosperity (Osoba, 1995). Observations by the researchers have shown that many female students in tertiary institutions are in this practice. According to them, it is more lucrative now as a student in the campus because men no longer patronize brothels and street prostitutes rather they prefer students. The campus situation is so bad to the extent that professional prostitutes are hail bent to gain admission into higher institutions.

Olugbile, Abu and Adelakun (2008) opined that sexual promiscuity is very rampant in our Universities and the average campus has several networks. Most of these students stand outside their hostels and halls to solicit for business. The hardened ones who see their campuses as too boring do not operate inside the University campuses. They brazenly take their trade directly to their customers at night to nearby cities, clubs or hot spots that would give them maximum exposure to men who will like to patronize them. However, the reader may wonder why promiscuity would be flourishing inside university campuses under the very nose of the staff and security agents. One of the reasons the researchers believe is that the university authorities have failed to strike the right balance between ensuring students' liberty and enforcement of existing campus codes of conduct. This is based on the premise that the students are adults that should be able to take care of themselves independent of their parents.

In addition to this, Uzokwe (2008) posited that with unbridled liberty and freedom the students began to push the limits of acceptable behaviour, taking advantage of freedom bestowed on them as "adults".

At this point, one would ask, what is the actual cause of sexual promiscuity or prostitution among our female undergraduates? According to Uzokwe (2008), one of the causes is dereliction of parental responsibilities. Many years ago, families in Nigeria put a lot of premium on morality, honour and character. Parents took time to bequeath same to their wards during their formative years. There were injunctions and periodic denial of basic necessities for doing things that impinge the family name. Vices like promiscuity, stealing and the like when displayed by a member of the family are capable of soiling the family image. No 
family would want to be blacklisted or blackmailed so parents paid serious attention to the moral and social welfare of their children, at times taking corrective actions when bad behaviours were detected. Compare this day to the ages past, certain behaviours that would repulse people no longer do. The reverse seems to be the case.

On the other hand, teachers these days no longer play the invaluable traditional roles they used to. They are no longer character builders because children have grown 'wings and tails'. These children, especially the female ones, feel they have the protection of their parents and or boy friends. Consequently, young girls go through school exhibiting signs of unacceptable behaviour which metamorphose into bigger issues in future with no one to stop or correct them. Eventually, those who find their ways into the universities end up continuing on a larger scale what they started in secondary schools.

Again, Olugbile (2008) wrote that peer influence is everywhere in the campus where everyone wants to be like others and end up prostituting. The bad girls that embrace prostitution gradually corrupt the more conservative ones. If for example one person had three cell phones, flashy clothes, another wants to do same or more. For those who are probably not from very rich homes they are forced to do otherwise.

Furthermore, some universities are not helping matters. Their fees are so much that it is hard to understand where they expect the students to get the money from. Being in a precarious condition, they turn to prostitution based on the fact that they are looking for money to settle their school bills.

Equally, Misi (2008) also pointed out that the politicians and government officials are not left out in the cause of female students' sexual promiscuity. According to him, anytime these politicians and government officials visit the university town on official work, the pimps recruit for them young university girls for their relaxation and entertainment, at the end of which they settle them with huge sums of ill gotten money (Olubgogega, 2008). Due to the fact that the girls glorify wealth, some of them therefore do what it takes to belong by taking to promiscuity.

On the issue of the effect of sexual promiscuity on healthy living, Janice (2008) intimated that sexually transmitted diseases like gonorrhoea, syphilis, Candida, herpes virginalis and worst of all HIV/AIDS are alarmingly high among girls who are sexually promiscuous. Drugs like cocaine, marijuana and alcohol are used most frequently by these girls at the expense of their health. They are also 
mostly under the influence of "psychotropic drugs" that put them in a state of fearlessness and shamelessness.

In the same vein, Gultmacher (1988) opined that most cases of infertility are caused by being promiscuous thereby being infested by numerous infected customers or acquaintances. Most female or male infertility, he added, can be attributed to husbands or wives who patronize sex hawkers and bring home infections and sexually transmitted diseases. In what becomes a vicious cycle, infertility may lead to divorce and in some cases the abandoned wife goes into prostitution as a means of survival. Again, physical injuries and bruises may also lead to general break down in health condition. Furthermore, most of the girls in this practice are sometimes physically assaulted by their "purchasers" who might be acting under the influence of hard drugs (Janice, 2008).

\section{Statement of the Problem}

Owing to the fact that most of these female undergraduates move out with unknown clients, Uzokwe (2008) opined that they are easy tools in the hands of ritual killers and kidnappers. Further, when a woman accepts money for sex, she has conferred on the man the authority and power to decide what kind of sex to happen, she would be expected to endure brutality, rape and other crime against her behind closed door. The prevalence and sophistication in promiscuous behaviour of the female undergraduates as intimated by Olugbile and Uzokwe (2008) is enough to trigger a discourse. The researchers wonder if the female undergraduates are ignorant or lack awareness of the health implications of promiscuousness.

The focus of the study is on the health implication of sexual promiscuity and the role of counselling in providing information services about its inherent health implications

\section{Purpose of the Study}

Against this background, this study set out to:

Investigate the prevalence of sexual promiscuity among female students in tertiary institutions; and find out the causes of sexual promiscuity among the female undergraduates.

Specifically, the effect of this behaviour as an issue for healthy living is a concern.

\section{Research Questions}

Three research questions guided this study. They are: 
1. Does sexual promiscuity exist among female students in tertiary institutions?

2. What are the causes of sexual promiscuity among female undergraduates?

3. What are the effects of sexual promiscuity?

\section{Methodology}

The design was a descriptive survey type that elicited information from the respondents on issues relating to sexual promiscuity and its attendant health problems. The population for the study comprised all the final year regular degree female students of four tertiary institutions in Imo State with an estimated population of 9,800.

Table I: Population Size of the Study

\begin{tabular}{|l|l|r|r|r|}
\hline S/N & \multicolumn{1}{|c|}{ Institutions } & Male & Female & Total \\
\hline 1. & Imo State University, Owerri & 1,200 & 1,600 & 2,800 \\
\hline 2. & $\begin{array}{l}\text { Alvan Ikoku Federal College of } \\
\text { Education, Owerri }\end{array}$ & 800 & 1,900 & 2,700 \\
\hline 3. & Federal Polytechnic Nekede, Owerri & 700 & 2000 & 2,700 \\
\hline 4. & $\begin{array}{l}\text { Federal University of Science and } \\
\text { Technology, Owerri }\end{array}$ & 13,00 & 300 & 1,600 \\
\hline & Total & $\mathbf{4 , 0 0 0}$ & $\mathbf{5 , 8 0 0}$ & $\mathbf{9 , 8 0 0}$ \\
\hline
\end{tabular}

Stratified/proportionate random sampling technique was used to ensure that each sample was representative of the population. Four percent $(4 \%)$ of the estimated population of students was used. Thus, the sample size is 415 . This is to ensure that the study can be generalised. Structured questionnaire was used to collect necessary data for the study. The questionnaire consists of two sections. Section one consists of personal data while section two consists of items derived from the content of the research question. A 4 point Likert scale of Strongly Agree (SA) Agree (A) strongly disagree (SD) and Disagree (D) was used for the data collection. The subjects were asked to indicate their degree of agreement with the statements contained in the instrument. In order to establish the content validity of the instrument, copies of the questionnaire were given to two experts in educational psychology and measurement and evaluation. Their corrections and suggestions were effected and integrated in the final production of the questionnaire. The questionnaires were administered directly by the researchers to the 
selected sample for the study. Simple percentage was used to analyze the responses.

From the data collected, four hundred and fifteen completed questionnaires were analyzed. Tables were used to present the data in relation to the research questions. Analysis was made using percentages.

\section{Table 2: Research Question One}

Does sexual promiscuity exist among our female undergraduates in tertiary institutions?

Table 2: Responses on Research Question One

\begin{tabular}{|c|l|c|c|c|c|c|}
\hline \multirow{2}{*}{ S/N } & \multicolumn{1}{|c|}{ Items } & $\begin{array}{c}\text { SA/ } \\
\text { A }\end{array}$ & $\mathbf{~ \% ~}$ & $\begin{array}{c}\text { SD/ } \\
\text { D }\end{array}$ & \% & Total \\
\hline 1. & $\begin{array}{l}\text { Promiscuity is rampant } \\
\text { among female students. }\end{array}$ & 344 & 83 & 71 & 17 & $\begin{array}{c}415 \\
(100 \%)\end{array}$ \\
\hline 2. & $\begin{array}{l}\text { Female students engage in } \\
\text { sex with many partners. }\end{array}$ & 315 & 76 & 100 & 24 & $\begin{array}{c}415 \\
(100 \%)\end{array}$ \\
\hline 3. & $\begin{array}{l}\text { Female students go out at } \\
\text { night to seek male } \\
\text { customers }\end{array}$ & 303 & 73.2 & 112 & 26.6 & $\begin{array}{c}415 \\
(100 \%)\end{array}$ \\
\hline & $\begin{array}{l}\text { Female students stand } \\
\text { outside their hostels, go to } \\
\text { nearby cities or hot spots } \\
\text { that would give them } \\
\text { maximum exposure to } \\
\text { men. }\end{array}$ & 349 & 84 & 66 & 16 & $\begin{array}{c}415 \\
(100 \%)\end{array}$ \\
\hline & Total \% & $\mathbf{1 3 1 1}$ & $\mathbf{3 1 6}$ & $\mathbf{3 4 9}$ & $\mathbf{8 4}$ & \\
\hline & Average \% & $\mathbf{3 2 8}$ & $\mathbf{7 9 \%}$ & $\mathbf{8 7}$ & $\mathbf{2 1 \%}$ & $\begin{array}{c}415 \\
(100 \%)\end{array}$ \\
\hline
\end{tabular}

Table 2 revealed questionnaire items $1-4$, which sought to find out information on the prevalence of sexual promiscuity among female students in tertiary institutions. The results indicated that $79 \%$ of the respondents agreed that it existed while $21 \%$ disagreed with its prevalence.

Conclusion was drawn from this result that sexual promiscuity actually existed among female undergraduates.

\section{Table 3 Research Question Two}

What are the causes of sexual promiscuity among female undergraduates? 
Questionnaire items 5-8 were used to analyze the above research question.

Table Two: Responses on Research Question Two

\begin{tabular}{|c|c|c|c|c|c|c|}
\hline \multirow[b]{2}{*}{$\mathrm{S} / \mathrm{N}$} & \multirow[b]{2}{*}{ Items } & \multicolumn{4}{|c|}{ Responses } & \multirow[b]{2}{*}{ Total } \\
\hline & & $\begin{array}{c}\text { SA } \\
\text { A }\end{array}$ & $\%$ & $\begin{array}{c}\text { SD } \\
\text { D }\end{array}$ & $\%$ & \\
\hline 5. & $\begin{array}{l}\text { Poverty causes } \\
\text { prostitution among female } \\
\text { undergraduates. }\end{array}$ & 328 & 79 & 87 & 21 & $\begin{array}{c}415 \\
(100 \%)\end{array}$ \\
\hline 6. & $\begin{array}{l}\text { Prostitution is attributed to } \\
\text { peer pressure. }\end{array}$ & 320 & 77 & 95 & 23 & $\begin{array}{c}415 \\
(100 \%)\end{array}$ \\
\hline 7. & $\begin{array}{l}\text { Dereliction of parental } \\
\text { roles on their children lead } \\
\text { to sexual } \\
\text { promiscuity/ prostitution. }\end{array}$ & 286 & 69 & 129 & 31 & $\begin{array}{c}415 \\
(100 \%)\end{array}$ \\
\hline 8. & $\begin{array}{l}\text { The uncontrolled liberty } \\
\text { and freedom to students } \\
\text { which made them push } \\
\text { beyond limits of } \\
\text { acceptable behaviour. }\end{array}$ & 282 & 68 & 133 & 32 & $\begin{array}{c}415 \\
(100 \%)\end{array}$ \\
\hline & Total $\%$ & 1216 & $23 \%$ & 444 & $127 \%$ & \\
\hline & Average $\%$ & 304 & $73 \%$ & 111 & $27 \%$ & $\begin{array}{c}415 \\
(100 \%)\end{array}$ \\
\hline
\end{tabular}

From the above table, items $5-8$ tried to answer research question two which dealt with the causes of sexual promiscuity among female undergraduates. The result indicated $73 \%$ as positive responses and $27 \%$ as negative responses. The positive respondents agreed that poverty, peer pressure, dereliction of parental roles, unbridled liberty and freedom to students attributed prostitution among female students in tertiary institutions to these factors.

\section{Research Question Three}

What are the effects of sexual promiscuity?

Questionnaire items 9 - 12 were used to analyze the research question. 
Table 4: Responses on Research Question Three

\begin{tabular}{|c|c|c|c|c|c|c|}
\hline \multirow[b]{2}{*}{$\mathrm{S} / \mathrm{N}$} & \multirow[b]{2}{*}{ Items } & \multicolumn{4}{|c|}{ Responses } & \multirow[b]{2}{*}{ Total } \\
\hline & & $\begin{array}{c}\text { SA } \\
\text { A }\end{array}$ & $\%$ & $\begin{array}{c}\text { SD } \\
\text { D }\end{array}$ & $\%$ & \\
\hline 9. & $\begin{array}{l}\text { Sexual promiscuity } \\
\text { leads to unwanted } \\
\text { pregnancy. }\end{array}$ & 336 & 81 & 79 & 19 & $\begin{array}{c}415 \\
(100 \%)\end{array}$ \\
\hline 10. & $\begin{array}{l}\text { It leads to intake of } \\
\text { drugs. }\end{array}$ & 334 & 83 & 81 & 17 & $\begin{array}{c}415 \\
(100 \%)\end{array}$ \\
\hline 11. & It leads to ST diseases. & 323 & 78 & 91 & 22 & $\begin{array}{r}415 \\
(100 \%) \\
\end{array}$ \\
\hline \multirow[t]{3}{*}{12.} & $\begin{array}{l}\text { It leads to social } \\
\text { stigma. }\end{array}$ & 291 & 70 & 125 & 30 & $\begin{array}{c}415 \\
(100 \%)\end{array}$ \\
\hline & Total \% & 1284 & 312 & 376 & 88 & \\
\hline & Average \% & 321 & $78 \%$ & 94 & $22 \%$ & $\begin{array}{c}415 \\
(100 \%)\end{array}$ \\
\hline
\end{tabular}

Table 4 sought to find out information on the effects of sexual promiscuity using question items $9-12$. The items dealt on unwanted pregnancy, drug intake, sexually transmitted diseases and social stigma among others as the effects of being sexually promiscuous. The average number of respondents 321 accounting for $78 \%$ that responded positively to these effects, and only $22 \%$ who did not consider the items as consequence of promiscuity.

\section{Discussion}

The findings in Table 2 indicated that sexual promiscuity actually exists among female undergraduates. These findings corroborate with Uzokwe (2008) who posited that prostitution is very rampant in Nigerian universities. He said that our young girls sent to the universities to acquire knowledge and become productive citizens found a vocation in prostitution. Misi ((2008) added that professional prostitutes are everywhere in the campuses as undergraduates, because according to him "men now prefer students to street prostitutes". Olugbile, et al (2008) opined that female students now trade with their bodies to earn huge income.

Further findings in Table 3 revealed that poverty, peer influence, poor parental supervision and unbridled liberty and freedom are attributed to the causes of prostitution. This result is in line with the assertion of Uzokwe (2008) who posited that prostitution is a lucrative 
business in institutions of higher learning. In his contribution, Olugbogega (2008) opined that economic crises and unemployment contribute to prostitution by our female undergraduates.

On the other hand, unwanted pregnancy, drug taking, depression, sexually transmitted diseases and other health problem such as infertility are some of the effects of promiscuity. This is in line with the view of Janice (2008) that the effects of prostitution include sexually transmitted diseases like gonorrhoea, syphilis, herpes, Candida and HIV/AIDS. Abortion, miscarriages, stress, severe trauma, anxiety and general poor health condition are also associated to promiscuousness (Osoba, 1995). The above findings call for the following under listed recommendations.

\section{Recommendations}

1. The researchers recommend that parents and teachers should be firm as role models. Parents should insist on acceptable behaviour of their children starting from their tender age in compliance to the bible injunction "teach a child the way he should go and when he grows, he will not depart from it".

2. The issue of indecent dressing should be included in the matriculation oath and students who violate the rule should be disciplined.

3. Seminars and workshops should be organized periodically on the dangers of promiscuousness in our healthy lives.

4. HIV/AIDS orientation should be organized for greater awareness by the guidance and counselling department of every tertiary institution.

5. The counselling department should embark on dissemination of valid HIV/AIDS information to students, staff and the community through:

(a) the use of audio-visual aid like films, films trips, slides, overhead projectors, bulletin board among others.

(b) Use of electronic media like the internet where it is available, usable and accessible.

(c) HIV/AIDS information being integrated into school subjects like biology and health education so as to catch them young.

6. The government, Ministry of Health and some NGOs should extend the fight against HIV/AIDS a bi-product of sexual promiscuousness to higher institutions and secondary schools where there is a larger group of people who are vulnerable to infection. 
7. Some institutions are relaxing on the post JAMB examination for entry into the university. Such relaxation would enable mediocentres into our institutions and frequently promote promiscuousness in our institutions. Thus the post UME need be fortified.

\section{Conclusion}

The high prevalence of sexual promiscuity in institutions of higher learning calls for reflection more so as it relates to healthy living. Sadly, available data attest a steady rise in the number of people being infected by HIV/AIDS and consequently, a dangerous future (Ugwuegbulam, 2001) citing Uwakwe, Mansaray and Onwu (1994). The practice with its attendant effects on healthy living is an evil wind that blows no good on the perpetrator and the general public. Hence, it should be discouraged by all and sundry in order to maintain healthy female products of the tertiary institutions with its attendant productive family living.

\section{References}

Gultmacher, A. Institute publication (1988), young women sexuality reproductive lives, htpp:/ / www.com.about.comm.

Janice, G.R. (2008) Making the harm visible Global speaking out and providing services, Health Effects of Prostitution. Retrieved July 25,2008

from

htpp://www.Uri.edu/artsci/wms/Hughes/mhvhealth.htm

Misi, O. K. (2008), Nigeria: When University Become Brothers, Retrieved July 26, 2008 from htpp://www.Africanloft.com/Universityorbrothel .

Olugbile, S Abu, and Adelakun, (2008), The Punch: Prostitution takes a New Garp on campuses. Punch on line Web Retrieved July 25, 2008 from htpp://www.punching.com/article.aspx? theatricart,

Olugbogega, (2008), Selling sex, female street Prostitution, And HIV risky behaviour care, htpp://www.searchlife.com.

Osoba, P. (1995), Be in Good Health. Benin; Osaba Publications.

Ugwuegbulam, C. N. (2001), HIV/AIDS Guidance Services (A gender sensitive approach). Owerri; Joe Mankpa's Publishers.

Uzokwe, A. O. (2008), Nigerworld, Prostitution in Nigerian campuses (part I) Retrieved July 21, 2008 from htpp://www.yahoo.com.

Uzokwe, A. O. (2008), Nigerworld, prostitution in Nigeria campuses (part II) Retrieved July 21, 2008 from htpp:/ / www.yahoo.com .

Wehmeire, S. (2000). Oxford Advanced Learners Dictionary of current English, sixth edition, Oxford University Press. 